\title{
Constitutional Right to Education in South Africa: A Myth or a Reality?
}

\author{
Lufuno Nevondwe \\ Kola O. Odeku \\ Faculty of Management and Law, School of Law, \\ University of Limpopo, South Africa \\ E-mail: lufuno3@gmail.com
}

Doi:10.5901/mjss.2013.v4n13p847

\begin{abstract}
There has been continuous heated debates in South Africa regarding whether the constitutional rights to access education is being fulfilled or not. This article highlights the inherent rights to education as mandated by the constitution and argues that despite the constitutional mandates, majority of the people, especially the less privileged and the vulnerable are still facing tremendous difficulties in order to access this fundamental right. The article examines various strategic policies and legal interventions that have been put in place to ensure that the constitutional mandate is fulfilled and realized.
\end{abstract}

Keywords: Access to education, Deprivation, previously disadvantaged, strategic policy and legal interventions

\section{Introduction}

In terms of section 29 of the South African Constitution of 1996, everyone has the right of access to education, including vulnerable persons. The State is obliged, to take reasonable legislative and other measures, within its available resources to achieve the progressive realisation of this right (Pieterse, 2007).

The right to education is widely recognised at both international and national levels as a fundamental right upon which the full exercise of several other rights is dependent. Nowak (2001) asserts that the importance of entrenching the right to education is based on certain premises. That is, the enjoyment of a number of civil and political rights, such as freedom of information and the right to vote depend on a minimum level of education, including literacy. Economic, social and cultural rights, such as the right to a choose career path or to take part in cultural life, can also only be exercised meaningfully if a minimum level of education has been achieved. Secondly, through education, individuals can be taught values such as tolerance and respect for human rights. Education therefore can strengthen a culture of human rights within and amongst nations (Brand and Heyns, 2005).

One of the regrettable setbacks in educational sector in South Africa is what Veriava (2002) described as racially skewed access to education perpetuated by the ousted apartheid regimes, which included a deliberate policy of unequal financing of educational institutions and deeply entrenched patterns of discrimination. This left legacies of discrimination and segregation in all spheres of life for many individuals and communities (Veriava, 2002).

The rights to vote, freedom of expression, information and association, labour rights and the right to participate in the cultural life of one's community are all intrinsically linked to education rights. These rights can only be meaningfully exercised in the context if a certain minimum level of education have been achieved (Small and Grant, 2005).

The idea that the objective of education is to enable a person to fully participate and function in society, in all its facets, is also consonant with the values expressed in the Preamble to the South African Constitution, which states, inter alia, that the Constitution was enacted to "free the potential of each person." (McCrudden, 2008).

\section{The Legacy of Apartheid on Education}

During the apartheid regime, education was structured along racial lines to prepare learners from different race groups for the roles they were expected to take in a divided South Africa. The main features of the apartheid education system were huge inequality in the financing of education, different curricula for different race groups and restricted access of black learners to higher education (Vandeyar, 2008).

The differences in education for different races were vast. White schools had many facilities, such as swimming 
pools, textbooks, laboratories, soccer and rugby fields. In contrast, African learners, especially rural learners walked long distances to schools and operated with few facilities without proper sanitation, running water or electricity (Enoch, 2007).

Today, while schools may not discriminate on racial grounds and must admit learners of all race groups, huge inequalities still exist between schools that were historically 'white' and schools that were historically 'black' (Lemon and Battersby-lennard, 2009). This is mainly because of the way schools are currently funded. The Government contributes funds to all public schools, but these funds are not enough to improve and maintain schools at a high standard, or to employ sufficient numbers of educators at all schools (Tomasevski, 2003). Schools are therefore allowed to charge school fees to augment the government funding (South African Schools Act 84 of 1996) (Gordon et. al. 2006).

The effect of this system of funding is that schools in wealthier communities, mainly the historically white schools, charge higher school fees and maintain a high standard of education with sufficient numbers of educators and good teaching facilities (Baine and Mwamwenda, 1994). Many schools in poor areas, predominantly African schools, cannot generate high school fees and therefore continue to deteriorate (Smith and Stovall, 2008). The government has introduced a system where $60 \%$ of schools particularly in rural areas are no longer charging school fees (Patrinos, 2000). The feeding schemes have also been introduced in both primary and secondary schools (Harber and Muthukrishna, 2000).

\section{International Law Perspective}

The right to education is recognised in Article 26 of the Universal Declaration of Human Rights (1948) and Article 13 and 14 of the International Covenant on Economic, Social and Cultural Rights (1966). The Committee on Economic, Social and Cultural Rights (CECSR) has prime responsibility for monitoring socio-economic rights, including the right to education (Beiter, 2006). The Committee has, to this end, issued a number of general comments in which the rights enumerated in CESCR are given content. Article 13 of the Covenant provides that education is both a human right in itself and an indispensable means of realizing other human rights (Griffey, 2011). "As an empowerment right, education is the primary vehicle by which economically and socially marginalized adults and children can lift themselves out of poverty and obtain the means to participate fully in their communities." (Aderinoye et al. 2007). Education has a vital role in empowering women, safeguarding children from exploitative and hazardous labour, sexual exploitation, promoting human rights and democracy, protecting the environment, and controlling population growth (Mulinge, 2002). Admittedly, education is recognized as one of the best financial investments States can make (Weisbrod, 1962). The importance of education is not just practical: a well-educated, enlightened and active mind, able to wander freely and widely, are the many joys and rewards of human existence (Beiter, 2006).

As pointed out earlier South Africa has signed the CESCR but has not yet ratified it. Article 12 of the Vienna Convention on the Law of Treaties, 1969 stipulates that the consent of a State to be bound by a treaty is expressed by the signature of its representative. This means that South Africa is bound by CESCR even though they have not yet ratified it.

The fundamental question is how the obligations relating to the right to education undertaken by Member States under international and regional instruments are incorporated into national legal systems? (Buergenthal et al.2006). This is chiefly important for achieving the Dakar goals in keeping with the commitments made by Governments for providing education for all especially free and compulsory quality basic education (Nilsson, 2003). Inspite of such legal obligations and political commitments, millions of children still remain deprived of educational opportunities, many of them on account of poverty (Sengupta, 2010). They must have right of access to basic education, particularly primary education which must be free (Bruns, 2003). Poverty must not be a hindrance to education and the claim by the poor to such education must be recognized and reinforced (Minujin et al. 2005).

The right to education is widely recognised in regional instruments (Nilsson, 2003). The right is included in the European Convention for the Protection of Human Rights and Fundamental Freedoms (European Convention) (1953). It is also included in the American Declaration of the Rights and Duties of Man (1948) and the Protocol of San Salvador to the American Convention on Human Rights (1988).

In the African region, the right to education is entrenched in Article 17 of the African Charter on Human and Peoples' Rights, 1981. Article 11 of the African Charter on the Rights and Welfare of the Child (1990) also provides for the right to education.

The right to education is also recognised in a number of international instruments dealing with the rights of specific vulnerable groups (Chapman, 1996), in particular, Articles 23(3) and (4), 28 and 29 of the Convention on the Rights of the Child (1989) (CRC) contain extensive provisions with regard to the progressive realisation of the right of the child to education and the aims of education. A final relevant instrument ratified by South Africa is the UNESCO Convention 
Against Discrimination in Education (1960). In essence, this means that South Africa must develop domestic policies and legislation entrenching this right of education to children (Veriava and Coomans, 2005).

\section{The Right to Education in Terms of the South African Constitution}

Section 29 of the South African Constitution has all the provisions which call for the right to education to be enforced by the State and all the people of South Africa. These provisions are as follows:

"29. Education.--(I) Everyone has the right-

(a) to a basic education, including adult basic education; and

(b) to further education, which the State, through reasonable measures, must make progressively available and accessible.

(2) Everyone has the right to receive education in the official language or languages of their choice in public educational institutions where that education is reasonably practicable. In order to ensure the effective access to, and implementation of, this right, the State must consider all reasonable educational alternatives, including single medium institutions, taking into account-
(a) equity;
(b) practicability; and
(e) the need to redress the results of past racially discriminatory laws and practices.
(3) Everyone has the right to establish and maintain, at their own expense, independent educational institutions that-
(a) do not discriminate on the basis of race;
(b) are registered with the State; and
(c) maintain standards that are not inferior to standards at comparable public educational institutions.

(4) Subsection (3) does not preclude State subsidies for independent educational institutions".

Section 29 of the Constitution can be described as a 'hybrid right'. This is because section 29 is a socio-economic right that says the Government must make education accessible and available to everyone (Arendse, 2011). But, it is also a civil and political right, as it contains freedom of choice guarantees, such as language choice in schools and the freedom to establish and maintain independent educational institutions. Individuals thus have the freedom to choose between State-organised schools and private education. In the 1996 case of In re: The Schools Education Bill of 1995 (Gauteng) (Schools Education Bill case), 19964 BCLR 537. The Constitutional Court commented on the constitutional right to basic education:

This provision creates a positive duty that basic education be provided for every person and not merely a negative right that such a person should not be obstructed in pursuing his or her basic education" (Paragraph 9 of the judgment).

In the School's Education Bill case, the Constitutional Court thus recognised that there is a positive obligation on the part of the State to provide basic education, but it has yet to comment in detail on the scope and the content of this right (Liebenberg, 2002).

An important feature of the right to basic education is that it is an unqualified socio-economic right. It is therefore different from the qualified socio-economic rights, such as the rights to health, housing, food, water and social security (Liebenberg, 2002).

\section{Constitutional Obligations}

Section 7(2) of the Constitution enjoins the State to "respect, protect, promote and fulfil the rights in the Bill of Rights." This duty implies that the State must protect people against invasion by the private sector. This would call for the State to protect individuals from discrimination in private educational institutions. It would also mean that the State would have to protect individuals from interference by other individuals or private companies in the exercise of their right to education. For example, the State would have to protect children from working as it would interfere with their right to education (Dworkin and Dworkin, 1978).

This duty would seem to imply that the State should actively inform people of their right to education and explain how they can gain access to this right. This duty is related to the whole idea of bringing human rights to the people. It would include activities such as workshops, seminars and publications in the written media and other mediums, such as radio and television (Dworkin and Dworkin ,1978).

The right to education is analysed as a continuum of three bands of schooling namely General Education and Training, Further Education and Training and Higher Education and Training. The State instituted measures to respect, 
protect, promote and fulfil the right to General Education and Training, and in the overall assessment, the government has succeeded in achieving progressive realisation of this right (Andreopouos and Claude, 1997).

The Department of Education succeeded in ensuring that all targeted Early Childhood Development sites for children between the ages of five and six were operating. However, the Department acknowledges the challenge, which has budgetary implications, that only $13 \%$ of all children have access to the programme. In the context of a substantial increase in the rate of students' enrolment in primary schools between 1994 and 2010, the National Department focused on further increasing access to General Education and Training through reviewing public school financing and the system of school fee exemptions. The report highlights the shortcoming that some schools and Provincial Departments of Education failed to make parents aware of the school fee exemption.

While progress was made in eliminating instances where learners are forced to receive education in environments that are not conducive to teaching and learning, the report emphasised that more needs to be done to address infrastructure backlogs, especially when it comes to water and sanitation (Fiske and Ladd, 2004). The Department also made progress in developing a redistribution model for personnel and operating expenditure that would achieve equality of teaching quality and equality of learning outcomes in the schooling system from 2003/2004 onwards (Motala, 2007).

All stakeholders in education need to explore and come up with a definition of quality basic education which should be measurable and relatively easy to monitor. Conditions in farm schools were identified as hindrance to progress in the realisation of the right to General Education and Training (Nyamnjoh, 2006). The issue of street-children also has to be given some serious attention by all the relevant stakeholders. Amongst other recommendations to further observance of the right to General Education and Training, the report calls for better-published medium term strategies and improved spending on Adult Basic Education and Training. In the 2001 South African Census, 4,5 million people aged 20 years and older did not have a formal education and 4 million people only had primary schooling (Mackie, 2006).

Most of the developments in the Further Education and Training met the Constitutional requirement to respect, protect, promote and fulfil the right. Dinaledi, the programme that seeks to improve participation and performance of learners from historically disadvantaged backgrounds in Mathematics, Science and Technology (MST), reportedly surpassed its target of $10 \%$ students enrolling for MST in its first two years of implementation (Scott and Yeld, 2008). The development of Recognition of Prior Learning (RPL) is another development that contributes to the realisation of the right to Further Education and Training. RPL recognises non-formal and/or non-academic education. RPL also stands to maximise learning opportunities for those without formal and/or academic qualifications to acquire formal qualifications in Further Education and Training institutions, which must all be registered with the State (Scott and Yeld, 2008).

Areas where the State fell short of its obligations to progressively realise the right to Further Education and Training include: insufficient public education on school fee exemptions and insufficient Learner Support Materials and/or their late delivery. The report also highlights that participation rates in education by girl learners were being negatively affected by girls' involvement in income generating activities (Motala, 2007).

While Higher Education and Training is not explicitly recognised as a right in the Constitution, it obviously depends on the learning outcomes achieved in General and Further Education and Training (Dewey, 2004). Here, there seems to be room for improvement as the average graduation rate for university, university of technology and FET colleges students is $15 \%$; less than half the ideal average of $33 \%$. Key challenges associated with the Higher Education and Training band include assisting potential students with subject selection choices and career guidance at school and university level, as well as lowering the high costs of accessing higher education and applying to different tertiary institutions (Reed, 2008). The report recommends ensuring that admission requirements to tertiary institutions are transparent and fair, promoting indigenous languages as academic/scientific/legal languages, mobilising funds for bridging courses and improving access for mature and post-graduate students, including part time students.

\section{Policies, Legislations and Programmes which are Aimed at Implementing Educational Rights}

\subsection{Progress in the Realisation of the Right to Education}

The State has adopted a number of policies and legislative measures in its quest to realise the right to education (Osler and Starkey, 2005). The following are some of those policies measures, namely National Policy on the Management of Drug Abuse by Learners in Public and Independent Schools and Further Education and Training Institutions, School Safety Programme, Regulations to Prohibit Initiation Practices in Schools and Teacher Development.

The National Policy on the Management of Drug Abuse by Learners in Public and Independent Schools and Further Education and Training Institutions meets the constitutional obligation to respect the right to education. By introducing a policy on drug abuse in learning institutions, the State is being proactive in ensuring that the right to 
education is not jeopardised owing to drug abuse by both learners and educators.

The introduction of the Schools Safety Programme and Regulations to Prohibit Initiation Practices in Schools (SASA) contributes towards the protection of the right to education as these prevent the violation of the right by any third party. An amendment was made to section 8 of SASA). New subsections $(6,7,8$ and 9) were inserted after subsection 5 of section 8 of SASA. The amendment provides for due process in safeguarding the interests of the learner and any other party involved in disciplinary hearings (Kowalski, 2006).

It is common practice that some schools expel learners for not paying school fees (Mncube, 2009). This is a violation of the learners' right to education since these learners miss classes as a result of the expulsion for the nonpayment of school fees. It therefore, still stands that government have to take active steps to ensure that parents are aware of the school fees exemption thereby promoting the right to education.

While the State has introduced school fees exemption for parents who cannot afford to pay the school fees, some schools have not been willing to make parents aware of the exemption (Lemon, 2005). In this case the problem lies with schools that are not passing the message on to parents.

The provision of classrooms and related facilities to those schools that initially did not have these, for instance, in the Free State province in 2002, thirty (30) schools were housed under unacceptable conditions, the provision of classrooms and related facilities is another positive development that also contributes towards the fulfillment of the right to education as it enables learners and educators to do their work better in improved conditions.

The Teacher Development Programme could as well contribute to the realisation of the right to education if it indeed becomes a success, that is, if most underqualified/ unqualified educators receive training. The amendment that was made to the Employment of Educators Act towards the fulfilment of the right to education (Darling-Hammond and Sykes, 2003).

The amendment makes it possible for PEDs to appoint educators who have had a break in service without a School Governing Body's recommendation. This move is helpful particularly to rural schools where, in most instances, qualified educators are not available since most of them prefer teaching in urban areas to rural areas.

South Africa has made significant progress in terms of policy development in the educational sphere (Jansen and Sayed, 2001).The National Department of Basic Education was required to provide information on policy measures instituted to respect, protect, promote and fulfil the right to education (Vally, 2006). The following were policies and programmes instituted between the period 1994 - 2009 by the National Department of Basic Education towards the realisation of the rights pertaining to education.

- Early Childhood Development (ECD)

- Adult Basic Education and Training (ABET)

- Outcome Based Education (OBE), also known as Curriculum 2005

- Culture of Learning, Teaching and Service (COLTS)

- Education for Learners with Special Education Needs (ELSEN).

- Seta Training

The ECD, which was first introduced in 1996, is a multi-disciplinary programme, which required the establishment of inter-departmental committees at National and Provincial Departments of Education and their counterparts in the Health and Welfare Departments (Biersteker, 2010). The committees had to develop and promote a comprehensive and multidisciplinary approach to the welfare and development of young children from birth to nine years.

The right to adult basic education is provided for in the constitution, and ABET seeks to provide for that right through addressing the problem of adult illiteracy in the country (Baatjes and Mathe, 2004). The National DoE saw ABET as an important tool for social participation and economic development. The programme was targeted at groups that were historically disadvantaged in terms of education and training and its standards were based on the National Qualifications Framework (NQF) (Biersteker, 2010).

The objective of the NQF is to attain the structuring of formal education in order to adopt an outcomes-based approach through all tiers of the education system (Cross et al. 2002). In February 1998 two policy papers on ABET and the National Multiyear Implementation Plan (NMYIP), were issued by the National Department of Basic Education. The policy papers on ABET proposed that the provision for ABET be expanded from 370000 people in 1997 to 691875 by the year 2001, in order to reach about 2.5 million adults in the process. The NMYIP policy as part of its first phase was meant to commit all players, including non-governmental organisations, tertiary institutions, publishers, the private sector and trade unions, to set up mechanisms that would ensure sustainable, large scale delivery of adult basic education (Allais, 2003).

Another policy measure instituted by the National DoE for the progressive realisation of the right to education was 
OBE, which was geared at providing skills training for both youth and adults (Naicker, 2005). The OBE programme resulted in the restructuring of formal education, which was guided by the NQF and the South African Qualifications Authority (SAQA). Both the NQF and SAQA were designed to standardise an outcomes based approach through all tiers of the education system (Makina, 2011).

The COLTS campaign was meant to ensure the improvement of access to quality education for all (Harber, 2010). In line with this, whole school development strategies were undertaken by non-governmental organisations together with the district level of government and community structures. The National Department of Basic Education also instituted the ELSEN policy for learners with special needs, a byproduct of the White Paper No.1 on Education and Training (1995) (Carter and Francis, 1995). The policy identified the need for the transformation of 'Education Support Services' (ESS). A Green Paper that was released for public comments in August 1999 highlighted the need for changes to be made in the provision of education and training to cater for learners with special education needs (Ball, 2007). This would be done through prioritising their needs, in terms of developing the capacity of educators in the current system and revising training policies and legislations (Phiri, 2010).

In response to the question on how the above policy measures contributed towards the progressive realisation of the right to education, the National DoE stated that all the policies emphasised equal access to good quality education and training. National DoE also mentioned that the policies were reasonable and effective as all forms of discrimination were removed from the education system, and that specific measures were being taken to ensure that redress of past discrimination takes place (Van der Berg, 2007).

In response to the question on the norms and standards used by the National Department of Basic Education for the funding of schools, the report stated that a policy document outlining the norms and standards was published in the Government Gazette, No. 19347 on 12 October 1998. The policy on norms and standards became national policy on 1 April 1999, and was implemented in January 2000. The main aim of the policy measure was to remove the inequities in the distribution of public resources for education, within and across provinces (Wilson, 2004).

The policy meant that funding would be based on an equitable cost per learner and public spending would be channeled to the poorest schools. The policy was thus intended to give effect to the funding of schools in terms of the South African Schools Act 84 of 1996 (Lewis and Naidoo, 2004). On measures taken to address gender equality among educators, the National Department of Basic Education stated that the Gender Equity Task Team was set up in September 1996. The Task Team was meant to investigate gender issues and make recommendations for the establishment of a Gender Equity Unit (GEU). A report published in 1997 by the Task Team resulted in the formation of a GEU that was to be located at the Director- General's office with similar units established in provincial offices as well.

Policy measures instituted by some of the Provincial Departments of Education (herein after Provincial Department of Basic Education) on the right to education were in line with national policies. Most of the Provincial Department of Basic Education did not provide the period on which the policy measures and programmes were instituted (Berger, 2003).

As an example, the Eastern Cape established community based centres for a pilot project on ECD and the Northern Cape Department of Basic Education adopted a new policy for funding ECD centres as well as the policy on admission to these centres that ensured that all children were admitted on an equitable basis.

In Gauteng and KwaZulu-Natal, policy measures were developed to intensify the delivery of formal ABET programmes. The Mpumalanga DoE instituted a policy to ensure that the existing schools provide ABET programmes. The Northern Cape established Adult Learning Centres in the rural areas to cater for the educational needs of adults and youth. These centres also catered for street children and other disadvantaged groups. In the Western Cape, an interim policy measure for the establishment and funding of Community Learning Centres (CLC) was developed in order to provide ABET and make it more accessible to adult learners. The Eastern Cape also had a project called Ikhwelo, which provided skills development especially for rural women. The Gauteng Department of Basic Education also opened innercity schools for homeless people and street kids.

The Free State Department of Basic Education was the only province which provided information on OBE, This was introduced in grades 1 and 2, as required by the SAQA Act 58 of 1995. Schools of Industry have been designated for learners who needed rehabilitation. The Free State Department of Basic Education, as a means of ensuring the maintenance and improvement of education in grades where OBE had not been introduced, implemented the Register of Institutional Programmes in Public Schools, June 1997, in all schools. Ass a means of preparing for the implementation of the compulsory reception year (grade 1) in the Free State, a pilot project was also launched and 100 school sites with approximately 4000 learners were identified for this purpose. The pilot project was conducted to assess whether there are enough schools for learners who will need to be registered for grade 1. 


\subsection{Higher Education}

South Africa's transition from apartheid and minority rule to democracy requires that all existing practices, institutions and values are viewed anew and rethought in terms of their fitness for the new era (Van Wyk, 2006). Higher education plays a central role in the social, cultural and economic development of modern societies. In South Africa today, the challenge is to redress past inequalities and to transform the higher education system to serve a new social order, to meet pressing national needs, and to respond to new realities and opportunities. It must lay the foundations for the development of a learning society which can stimulate, direct and mobilise the creative and intellectual energies of all the people towards meeting the challenge of reconstruction and development (WPHE, 1997).

The transformation of the higher education system is being carried out to reflect the changes that are taking place in our society and to strengthen the values and practices of our new democracy (Fourie, 1999). The higher education system must be transformed to redress past inequalities, to serve a new social order, to meet pressing national needs and to respond to new realities and opportunities (Akoojee and Nkomo, 2007).

The White Paper outlines the framework for change, that is, "the higher education system must be planned, governed and funded as a single national co-ordinated system". (Leslie, 2010). This will enable the government to overcome the fragmentation, inequality and inefficiency which are the legacies of the past, and create a learning society which releases the creative and intellectual energies of all our people towards meeting the goals of reconstruction and development.

Higher education has several related purposes. In the context of present-day South Africa, they must contribute to and support the process of societal transformation outlined in the Reconstruction and Development Programme (RDP), with its compelling vision of people-driven development leading to the building of a better quality of life for all (SinghKagisano, 2001). These purposes are:

- "To meet the learning needs and aspirations of individuals through the development of their intellectual abilities and aptitudes throughout their lives. Higher education equips individuals to make the best use of their talents and of the opportunities offered by society for self-fulfilment. It is thus a key allocator of life chances, an important vehicle for achieving equity in the distribution of opportunity and achievement among South African citizens.

- To address the development needs of society and provide the labour market, in a knowledge-driven and knowledge-dependent society, with the ever-changing high- level competencies and expertise necessary for the growth and prosperity of a modern economy. Higher education teaches and trains people to fulfil specialised social functions, enter the learned professions, or pursue vocations in administration, trade, industry, science and technology and the arts.

- To contribute to the socialisation of enlightened, responsible and constructively critical citizens. Higher education encourages the development of a reflective capacity and a willingness to review and renew prevailing ideas, policies and practices based on a commitment to the common good.

- To contribute to the creation, sharing and evaluation of knowledge. Higher education engages in the pursuit of academic scholarship and intellectual inquiry in all fields of human understanding, through research, learning and teaching (WPHE, 1997).

Assessing the current state of higher education in South Africa against the yardstick of these four general purposes reveals that there is still a reason for concern and an imperative for transformation (Waghid, 2010). Despite acknowledged achievements and strengths, the present system of higher education is limited in its ability to meet the moral, political, social and economic demands of the new South Africa. The programme for the Transformation of Higher Education in South Africa, is characterised by the following deficiencies:

- There is an inequitable distribution of access and opportunity for students and staff along lines of race, gender, class and geography. There are gross discrepancies in the participation rates of students from different population groups, indefensible imbalances in the ratios of black and female staff compared to whites and males, and equally untenable disparities between historically black and historically white institutions in terms of facilities and capacities.

- There is a chronic mismatch between the output of higher education and the needs of a modernizing economy. In particular, there is a shortage of highly trained graduates in fields such as science, engineering, technology and commerce (largely as a result of discriminatory practices that have limited the access of black and women students to these fields of study), and this has been detrimental to social and economic development. 
- Higher education has an unmatched obligation, which has not been adequately fulfilled, to help lay the foundations of a critical civil society, with a culture of public debate and tolerance which accommodates differences and competing interests. It has much more to do, both within its own institutions and in its influence on the broader community, to strengthen the democratic ethos, the sense of common citizenship and commitment to a common good.

- While parts of the South Africa's higher education system can claim academic achievement of international renown, too many parts of the system observe teaching and research policies which favour academic insularity and closed system disciplinary programmes. Although much is being done, there is still insufficient attention given to the pressing local, regional and national needs of the South African society and to the problems and challenges of the broader African context.

- The governance of higher education at a system-level is characterised by fragmentation, inefficiency and ineffectiveness, with too little co-ordination, few common goals and negligible systemic planning. At the institutional-level, democratic participation and the effective representation of staff and students in governance structures is still contested on many campuses".

Despite the negative consequences of the apartheid legacy, some higher education institutions have developed internationally competitive research and teaching capacities. Their academic expertise and infrastructure are national assets. It would be detrimental to the national interest and the future provision of quality higher education if the valuable features and achievements of the existing system were not identified, retained and used in the restructuring process. However, if higher education is to contribute to the reconstruction and development of South Africa and existing centers of excellence maintained, the inequities, imbalances and distortions that has been derived from its past and present structure must be addressed, and higher education transformed to meet the challenges of a new non-racial, non-sexist and democratic society committed to equity, justice and a better life for all.

After the release of the Language Policy for Higher Education in November 2002, the then Minister of Education appointed a Ministerial Committee in 2003 to advice on a framework for the development of indigenous languages for use as languages of instruction in higher education. (First author personal communication with an official from the National Department of Education. The said official revealed that starting from February 2004, the Ministerial Committee was given about six months to investigate and report back to the Minister on the use of indigenous languages as languages of instruction in higher education).

Such a framework should, amongst [other things], address the following:

- "criteria for the selection of languages to be developed for use in higher education. (This may require an assessment of the current usage of indigenous languages in higher education);

- the number of languages that should be earmarked for development, [as well as the relevant] academic disciplines or fields of study;

- an identification of the key areas which will require attention, such as the development of dictionaries, teaching and learning materials, staff development, etcetera, and;

- the institutional arrangements required for implementation, including the respective responsibilities of higher education institutions and the Government".

In a broader view, the policy paper (the Language Policy for Higher Education) attempts to ensure the simultaneous development of a multilingual environment in which all languages are developed as academic/scientific languages, while at the same time ensuring that the existing languages of instruction in the higher education institutions do not serve as a barrier to access and success (LPHE, 2002).

Limited as may be, section 29(2) of the Constitution provides that everyone has the right to receive education in the official language or languages of their choice in public educational institutions where that education is reasonably practicable. As a secondary legislative piece, the Higher Education Act 101, 1997 specifically reinforces this right as it accords the Minister of Education the powers to determine language policy for higher education (National Plan for Higher Education (NPHE), 2001).

\subsection{Higher Education Act 101 of 1997}

The establishment of the National Higher Education Information and Applications Service (NHEIAS) is provided for in the National Plan for Higher Education (NPHE) of 2001. It was in this context, that in October of the same year, the Minister of Education appointed a Working Group to advise the Ministry on the establishment of a NHEIAS (2002).

The Working Group examined the structures and processes of four existing national applications services in other 
countries, those of the United Kingdom, Ireland, Kenya and Turkey. In addition, it looked closely at the established local regional office in KwaZulu-Natal (the esATI Central Applications Office]).

In its research into ways in which these services function, the Working Group took note of the size of the systems (the number of member institutions served), funding of the service, governance structures, legal constitution, and, most critically, the operating processes. The latter involved the handling of applications, selection, the construction of handbooks, fees, communication with institutions and applicants, the administration of admissions criteria, and the ICT platform to support the service (MOE, 2004).

Basically, the aim of this new development is to provide information, enable a single application to higher education institutions and therefore reduce the costs associated with applying to different tertiary institutions (Grubb, 2003). The central service will have to ensure that:

- "students are aware of the courses offered and institutions available;

- access to higher education, particularly for rural pupils, is promoted;

- the processing of students' applications and the provision of accurate statistics are managed better, and;

- the costs of applying for tertiary education [are] lower" (Monare, 2003).

\subsection{Funding of Public Higher Education: A New Framework}

This is one important development the Ministry began working on in 1998. Briefly, the "funding framework gives the Minister a direct control over government grants to the public higher education. This makes the new funding framework an ideal steering mechanism to be used to achieve national goals and objectives of higher education transformation. Moreover, the new funding framework was achieved through a wide consultation process between the Ministry and other stakeholders in higher education including Higher Education South Africa (HESA)."

A basic feature of the new framework is that it links the awarding of government higher education grants to national and institutional planning. This funding/planning link makes the new framework essentially a goal oriented mechanism for the distribution of government grants to individual institutions, in accordance (a) with national planning and policy priorities, (b) with the quantum of funds made available in the national higher education budget, and (c) the approved plans of individual institutions (MOE, 2004).

However, "it has taken the Ministry rather a long time to eventually produce a complete and comprehensive funding framework for higher education. The rationale for the long gap between the initiation of the developmental work and the release of the framework is largely due to the fact that, although the Education White Paper 3: A Programme for the Transformation of Higher Education (July 1997) outlined the principles that should guide the development of a new funding framework, key policy issues relating to the restructuring of the higher education system remained unresolved." These issues have been addressed in the NPHE, thus enabling the finalization of the new funding framework (MOE, 1997).

The new funding framework is informed by framework outlined in the Education White Paper. "It replaces the old funding framework introduced in 1982, which proved to be unsuitable as "a steering mechanism to achieve the policy objectives and goals for the transformation of higher education system". Apart from its origins in the apartheid past, it was based on "a market-driven model, which precluded its use as a steering mechanism to address national goals and objectives. The role of the Government in this model was limited to funding students' demand and to correcting market failures that could occur. However, under apartheid regime, the market model was itself distorted by ideological factors, which restricted and constrained institutional and students' choices and decisions."

\section{Progress and Challenges in Higher Education}

Assessing progress made by the State in availing higher education to the society, "may at this stage, prove to be a limited exercise given that at least most higher education institutions in the country are pre- occupied with transformation and restructuring - an ongoing process up-to-date. Ironically, mergers and incorporations that have already taken place in most higher learning institutions can be hailed as successful" (Altbach et al. 2009). However, the conclusion of the mergers and incorporations process only spells more challenges for the higher education sector (Hall et al. 2004). These comprise access to higher education, improvement of participation rates, representation of black and female staff, graduation trends, and et cetera. It is worthwhile discussing briefly each of the challenges facing the higher education sector (SAHRC, 2004). 


\subsection{Access to Higher Education}

Apart from relatively few numbers of matriculants who gained entry into higher learning institutions, "the high cost of tertiary education has often been cited as a barrier to accessing higher learning for most students. A Human Sciences Research Council survey found that almost three-quarters of grade 12 learners would like to proceed to higher education. The high cost of tertiary study is the biggest barrier to entering a tertiary institution. Most learners (55\%) intended to study at the University of Science and Technology, Further Education Training (FET) and 35\% intended to go to university" (SAHRC, 2004).

\subsection{The Right to Establish Private Educational Institutions}

Section 29(3) of the Constitution states that:

"Everyone has the right to establish and maintain, at their own expense, independent educational institutions that -

(a) do not discriminate on the basis of race;

(b) are registered with the State; and

(c) maintain standards that are not inferior in standards at comparable public education institutions."

In the School Education Bill of 1995 (Gauteng), the Court, interpreting the meaning of the equivalent provision under the interim Constitution, defined the extent of the State's obligation in respect of private education institutions based on a common language and culture as observed by the court in the Belgian Linguistic Case No 2 (1968) Series A No 61 EHRR 252.

The submission that every person can demand from the State the right to have established schools based on a common culture, language or religion is not supported by the language of section 32(c). The section does not say that every person has the right to have established schools by the State educational institutions based on such a common culture, language or religion. What it provides is that every person shall have the right to establish such educational institutions. Linguistically and grammatically it provides a defensive right to a person who seeks to establish such educational institutions and it protects that right from invasion by the State, without conferring on the State an obligation to establish such educational institutions.

The Court thus emphasized that the State's obligations in respect of minority rights in this context were limited to the protection of the rights of minorities to exist as a group, and not to be discriminated against, but that it did not extend to funding the establishment of institutions for particular minority groups. In other words, the Court identified obligations to respect and to protect, but not the obligation to fulfil.

The right of educational institutions to exist independently is, in terms of this section, conditional on meeting established criteria. That is, independent institutions may not discriminate against learners on the basis of race. Independent schools are also subject to the norms and standards set by the Department of Education and may only qualify for registration once certain basic criteria have been met in line with section 46 of the School Act.

The protection in terms of equivalent provisions under the Interim Constitution was only available to schools that were established in terms of a specific cultural or religious identity. The right in terms of the Final Constitution applies to all private schools. Thus, even private schools that do not exist because of a specific cultural or religious affiliation, such as Waldorf Schools, may demand the protection afforded by the right, provided of course, that the schools meet the established criteria.

While the State is not obliged to fund independent institutions, in terms of section 29(4) nothing precludes the State from granting such schools a subsidy. Such allocations should however, be guided by the values in the Constitution, in particular the principle of non-discrimination. Eligibility for subsidies at such schools is currently governed by the Schools Act (section 45 and 48 of the Schools Act which was developed in terms of section 9(3) and (4) of the South African Constitution (Bisschoff, 2009). The criteria for schools eligibility to subsidies are dependent on the socio-economic circumstances of the school's clientele. This is assessed by the level of fees charged at the schools, that is, those schools charging very low or no fees are more likely to qualify for a subsidy. Thus, while some may argue that such allocations amount to discrimination against those groups not benefiting from the subsidies, such targeting in fact demonstrates a commitment to redress and the principle of substantive equality. 


\section{Other Provisions in the Bill of Rights}

In addition to the specific protection guaranteed by the different subsections of section 29 , other provisions of the Bill of Rights also affect the rights and freedoms of learners and students while at educational institutions.

\subsection{The Principle of Equality and Equal Access}

Section 32(a) of the Interim Constitution specifically provided right of equal access to educational institutions. Such a provision is not included in the final Constitution, but the principle of equality remains central to the meaning of the different subsections of the educational clause. The principle of non discrimination "is intrinsic to the notion of accessibility that forms part of the right to basic education and further education. In giving effect to the right to education in a language of one's choice, regard must be given to the broader principle of equality, and independent educational institutions may only exist on the basis that they do not discriminate on the grounds of race. Nothing precludes a learner or student from asserting his or her right to equal access to an institution in terms of section 9, where such a right has been denied."

\subsection{Freedom of choice}

The basic freedoms in the education clause extend to language choice, and implied in section 29(3) is the freedom of an individual to attend the school of his or her choice. Other rights in the Constitution may also be asserted where these rights of learners and students are threatened within educational institutions.

These rights could include, but are not limited to the freedom of religion (Section 15) or the freedom of assembly (section 17). It is worth noting that, unlike certain international treaties where parental choice is explicitly entrenched, the education clause does not expressly give parents the right to choose to have their children educated according to their own religious and philosophical convictions.

Freedom of choice may be "curtailed to the extent that individual values conflict with broader societal values, in particular those set out in the Constitution, and it may be curtailed also by circumstances that is, a parent living in a particular area may prefer to send a child to a better resourced school in a different area, but may be constrained in his or her choice of school because of the un-affordability of transport costs and fees associated with sending a child to a better resourced school in a different area."

\section{Conclusion}

Based on the fact that most of the policies and legislative measures the State has introduced conform to the constitutional obligations as well as to the Grootboom judgment, a conclusion may be reached that the right to education is adequately provided for in terms of the practical policies and measures for its implementation.

However, there are shortcomings in the implementation of some policy measures. One example is the school fees exemption. Whilst the introduction of the school fees exemption was a reasonable action by the State to ensure that no school-going child is prevented from attending school as a result of lack of school fees, some schools have failed to make parents aware of the exemption.

According to an official from the Gauteng Department of Education, the poverty line to be used is R450 per learner. However, the official emphasised the point that the issue was still being discussed. Furthermore, the Grootboom judgment makes it clear that, in its quest to realise socio-economic rights, the State should examine legal, administrative, operational and financial hurdles and, where possible, lower these over time.

The lack of classrooms and related facilities in some schools is also being addressed by the State through donorfunding mobilisation, amongst other things. Again, the right is being progressively realised. In this case, the State has made an indication that financial resources are a major challenge in ensuring that all schools have access to decent facilities required for their education (IOL, 2010).

The Department of Basic Education succeeded in ensuring that all the targeted Early Childhood Development sites were operating and the net enrolment ratio in the General Education and Training sector was increased. There were other problematic areas that also hindered progress in the realisation of the right to education. These include, amongst others, the conditions of farm schools whereby in some instances the school-going children were not attending school because they were working on farms as a result of poverty and also as a result of parents not being informed in some schools about the school fees exemption (Segale, 2008). 


\section{References}

Aderinoye RA, Ojokheta KO, Olojede AA 2007. Integrating mobile learning into nomadic education programme in Nigeria: Issues and perspectives. From http://www.doaj.org/. (Retrieved July 21, 2012).

Akoojee S, Nkomo MO 2007. Access and quality in South African higher education: the twin challenges of transformation. From repository.up.ac.za, http://repository.up.ac.za/handle/2263/4423. (Retrieved March 4, 2012).

Allais SM 2003. The National Qualifications Framework in South Africa: A democratic project trapped in a neo-liberal paradigm? Journal of Education and Work, 16(3):305-323.

Andreopouos GJ Claude RP 1997. Human rights education for the twenty-first century, University of Pennsylvania Press, USA.

Arendse L 2011. The Obligation to Provide Free Basic Education in South Africa: An International Law Perspective, Potchefstroom Electronic Law Journal, 14(6):97-127.

Baatjes I, Mathe K 2004. Adult basic education and social change in South Africa (1994-2003), Pretoria: HSRC, 2004.

Baine D, Mwamwenda T 1994. Education in Southern Africa: Current conditions and future directions, International Review of Education, 40(2):113-134.

Brand D and Heyns C 2005. Socio-economic Rights in South Africa, Pretoria University Law Press, Pretoria, South Africa.

Ball SJ 2007. Education plc: Understanding private sector participation in public sector education, Routledge, New York, USA.

Beiter KD 2006. Right to Education by International Law: Including a Systematic Analysis of Article 13 of the International Convenant on Economic, Social and Cultural Rights, Matinus Nijhoff Publishers, The Netherlands.

Berger E 2003. Department of Education, The organization, governance and funding of schools: A draft policy document for discussion (Draft White Paper 2). From unl.edu. (Retrieved April 4, 2012).

Biersteker L, 2010. Scaling-up early child development in South Africa, Wolfensohm Centre for Development, Washington, USA.

Bisschoff T 2009. Financial school management explained, Pearson Educationa South Africa (Pty) Ltd, Cape Town, South Africa.

Bruns B, Rakotomalala R 2003. Achieving universal primary education by 2015: A chance for every child, World Bank Publishers, Washington, USA.

Buergenthal T, Shelton DL, Stewart DP 2009. International human rights in a nutshell. From scholarship.law.gwu.edu. (Retrieved August 2, 2012).

Carter H, Francis C 1995. Everyone a teacher, everyone a learner- North Central Region, From sustainableag.unl.edu. (Retrieved August 4, 2012).

Chapman AR 1996. A violations approach for monitoring the International Covenant on Economic, Social and Cultural Rights, Human Rights Quarterly, 18(1):23-66.

Cross C, Mungadi R Rouhani S 2002. Comparative Education From Policy to Practice: Curriculum reform in South African education, 28(2): 171-187.

Darling-Hammond L, G Sykes G 2003. Wanted, A national teacher supply policy for education: The right way to meet the" highly qualified teacher" challenge. From . http://epaa.asu.edu/ojs/article/view/261/387. (Retrieved May 17, 2012).

Dewey J 2004. Democracy and education, Macmillan, NY, USA.

Dworkin R, Dworkin RD 1978 . Taking rights seriously. From philosophyfaculty.ucsd.edu. (Retrieved February 4, 2012).

Enoch SD 2007. Guidelines for multicultural education in integrated schools with specific reference to the South African context. From zspace.uzulu.ac.za. http://uzspace.uzulu.ac.za/handle/10530/140. (Retrieved September 2, 2012).

Fiske EB, Ladd HF 2004. Elusive equity: Education reform in post apartheid South Africa, RR Donnelley, Harrisonburg Virginia, USA.

Gordon RJ, Kane TJ, Staiger D 2006. Identifying effective teachers using performance on the job, RR Dannelly, Harrisonburg, Virginia, USA.

Griffey B 2011. The 'reasonableness' test: Assessing violations of state obligations under the Optional Protocol to the International Covenant on Economic, Social and Cultural Rights, Human rights law review, 11 (2): 275-327.

Grubb WN 2003. The roles of tertiary colleges and institutes: Trade-offs in restructuring postsecondary education, World Bank, Washington, USA.

Hall M, Symes A, Luescher T 2004. The governance of merger in South African higher education. From thierry.konstruktiv.li. (Retrieved October, 10, 2012).

Harber C 2010. Chronicling educator practices and experiences in the context of democratic schooling and quality education in South Africa, International Journal of Educational Development, 30(6): 614-624.

Harber C, Muthukrishna N 2000. School Effectiveness and School Improvement in Context: The Case of South Africa, International Journal of Research, Policy and Practice, 11(4):421-434.

Higher Education Discussion Series. From ru.ac.za. (Retrieved September 22, 2012).

Jansen JD, Sayed Y 2001. Implementing education policies: the South African experience, UCT Press, Cape Town, South Africa.

Kowalski TJ 2006. The school superintendent: Theory, practice, and cases . Sage Publication International, Thousand Oaks, California, USA.

Lemon A 2005. Shifting geographies of social inclusion and exclusion: Secondary education in Pietermaritzburg, South Africa, African Affairs, 104 (414): 69-96.

Lemon A, Battersby-lennard J 2009. Overcoming the apartheid legacy in cape town schools, Geographical Review, 99(4):517-538.

Leslie MMC 2010. Exploring the developmental outcomes of service-learning in Higher Education for partner organisations: an exploratory study of two modules at Stellenbosch. From http://scholar.sun.ac.za/handle/10019.1/4242. (Retrieved March 4, 
2012).

Lewis SG, Naidoo J 2004. Whose theory of participation? School governance policy and practice in South Africa, Current Issues in Comparative Education, 2004. From- ethiopia-ed.net. (Retrieved July 9, 2012).

Liebenberg S 2002. South Africa's evolving jurisprudence on socio-economic rights: An effective tool in challenging poverty? From communitylawcentre.org.za. (Retrieved May 4, 2012).

LPHE, 2002. Language Policy for Higher Education, Ministry of Education, November 2002.

Makgoba MW 2009. Trends in global higher education: Tracking an academic revolution, Martinuf Nijoff Publishers and VSP, Amsterdam, Netherlands.

Makina BT 2011. Re-imagining the tapestry of teaching: an investigation into student teachers' Outcomes-Based Education (OBE) instructional practices. From http://umkn-dsp01.unisa.ac.za/handle/10500/5592. (Retieved May 9, 2013).

McCrudden C 2008. Human Dignity and Judicial Interpretation of Human Rights. European Journal of International Law, 19(4): 655-724.

Minujin A, Delamonica E, Gonzalez ED 2005. Children Living in Poverty. From unicef.org. (Retrived June 6, 2012).

Mncube M 2009. The perceptions of parents of their role in the democratic governance of schools in South Africa: Are they on board? South African Journal of Education, 29(1):1-7.

MOE 1997. Government Notice, Ministry of Education, Higher Education Act 101, 1997: Funding of Public Higher Education, 2003.

MOE 2004. Ministry of Education 2004, A New Funding Framework: How Government Grants Are Allocated To Public Higher Education Institutions, February 2004.

Monare M 2003. "Government to Choose Varsity Students: Education Department Wants Central Agency to Administer Admissions", Sunday Times, August 17, 2003.

Morris M, Reed L 2008. A sectoral analysis of skills gaps and shortages in the clothing and textile industry in South Africa, Report for the Human Sciences Research Council.

Motala S, Dieltiens V, Carrim N, Kgobe P, Moyo G 2007. Educational access in South Africa: Country analytic review. From http://sro.sussex.ac.uk/1873/. (Retrieved March 17, 2012).

Mulinge MM 2002.Implementing the 1989 United Nations' Convention on the Rights of the Child in sub-Saharan Africa: the overlooked socioeconomic and political dilemmas, Child Abuse \& Neglect, 26(11):1117-1130.

Naicker SM 2005. Inclusive education in South Africa-Contextualising inclusive education, 2005. Rutledge, Abingdon, UK.

NHEIAS, 2002. Report of the Working Group to the Minister of Education: The Establishment of a National Higher Education Information and Applications Service for South Africa, June 2002.

Nilsson P 2003. Education for All: teacher demand and supply in Africa, Education International Working Papers, United Nations Educational, Scientific and Cultural Organization, Routledge NY, USA.

NPHE, 2001. National Plan for Higher Education (NPHE) of 2001.

Nyamnjoh FB 2006. Insiders and outsiders: citizenship and xenophobia in contemporary Southern Africa, Zedbooks, NY, USA.

Osler A, Starkey H 2005. Changing citizenship: Democracy and inclusion in education, Open University Press, Berkshire, UK.

Patrinos HA 2000. Market Forces in Education, European Journal of Education, 35(1):26-38.

Phiri BJ 2010. Early childhood education in post apartheid South Africa: stakeholder involvement, policy initiatives and implementation. From wiredspace.wits.ac.za. (Retrieved July 4, 2012).

Pieterse M 2007. Eating Socioeconomic Rights: The Usefulness of Rights Talk in Alleviating Social Hardship Revisited, Human Rights Quarterly, 29(3):796-822.

SAHRC 2004. The Right to education, $5^{\text {th }}$ Economic and Social Rights Report Series 2002/2003 financial year, South African Human Rights Commission 21 June 2004, 73.

Scott I, Yeld N 2008. The interface between further and higher education in South Africa: Factors affecting the higher education sector's capacity to meet national needs, Council for Higher Education, Pretoria, South Africa.

Segale BM 2008. To teach and to manage: a case of principal-teachers in multi-graded classrooms in farm schools. From, https://ujdigispace.uj.ac.za/handle/10210/570.(Retrieved February 4, 2012).

Sengupta A 2010. Human rights and extreme poverty. From re.indiaenvironmentportal.org.in. (Retrieved August 6, 2013).

Singh-Kagisano M 2001. Re-inserting the public good into higher education transformation, From ru.ac.za. (Received July 19, 2012.

Small J, Grant E 2005. Dignity, discrimination, and context: New directions in South African and Canadian human rights law, Human Rights Review, 6(2):25-63.

Smith JJ, Stovall D 2008. Schools and the urban renaissance, Coming home' to new homes and new schools: critical race theory and the new politics of containment, Journal of Education Policy, 23(2):135-152.

Tomasevski K 2003. Education denied: Costs and Remedies, Zed Books, London, UK.

Vally S 2006. Education rights, education policies and inequality in South Africa, International Journal of Educational Development, 26(4):352-362.

van der Berg S 2007. Apartheid's enduring legacy: Inequalities in education- Journal of African Economies, 16 (5): 849-880.

Van Wyk B 2006. Exploring Constitutive Meanings of Educational Transformation in South Africa, Interchange, 37(3):181-199.

Vandeyar S 2008. Shifting selves: The emergence of new identities in South African schools, International Journal of Educational Development, 28(3):286-299.

Veriava F 2002. , Eradicating barriers to education: An Introduction to the Education Rights Project", ESR Review, Vol 3, 2 September 2002.

Veriava F, Coomans F 2005. The Right to Education, In: Brand D and Heyns CH (Eds), Socio-economic rights in South Africa, ABC 
Press, Cape Town, South Africa.

Waghid, Y 2010. The decline of educational research in South Africa: Reconstituting the place of reason. From saches.co.za. (Retrieved June 19, 2012).

Weisbrod BA 1962. Education and investment in human capital, The Journal of Political Economy, 1962, 70(5):106-113.

Wilson S 2004. Taming the Constitution: Rights and Reform in the South African Education System, South African Journal on Human Rights Conference, 5: 1-33. 